${ }^{\odot}$ Entomologica Fennica. 15 June 2001

\title{
Redescription of the larva of Siobla ruficornis (Gimmerthal, 1834) (Hymenoptera, Tenthredinidae) from East Finland
}

\author{
Matti Ahola
}

\begin{abstract}
Ahola, M. 2001: Redescription of the larva of Siobla ruficornis (Gimmerthal, 1834) (Hymenoptera, Tenthredinidae) from East Finland. — Entomol. Fennica 12: $28-32$.

The larva of Siobla ruficornis (Gimmerthal, 1834) is redescribed on the basis of specimens collected in East Finland (PS:Heinävesi) on 14 August 1999. Four larvae were found on Prunus cerasus and one on Rubus idaeus. Malaise (1932) briefly described ornaments of a larva found on Epilobium angustifolium in NE Asia. The habitus of Finnish larvae conforms closely to Malaise's description. Further characteristics are added here and drawings of mouthparts and colour picture of larva are given.
\end{abstract}

Matti Ahola, Metsänreunantie 27 G, FIN-85900 Reisjärvi, Finland; E-mail: matti@mahola.pp.fi

Received 14 March 2000, accepted 7 February 2001

\section{Introduction}

In August 1929, René Malaise found ca. 20 sawfly larvae in Kamtchatka, northeastern Asia, which later proved to belong to a new species, Siobla sibirica Malaise, 1932. He also described ornaments of the larva. Larvae were found on Epilobium angustifolium. The species has been found in eastern Finland, where it was first misidentified as Siobla sturmii (Klug, 1817) (Forsius 1919, Hellén 1935). Kontuniemi (1960) recorded it as S. ruficornis Cameron (= S. sibirica Malaise) and Viitasaari \& Vikberg (1985) merely listed $S$. ruficornis (Cameron 1876). Earlier Gimmerthal (1834) had described a sawfly species from Latvia under the name Allantus ruficornis, which according to Taeger (1991) is conspecific with Siobla ruficornis (Cameron). Thus, the first author of this species is Gimmerthal, 1834.

\section{Material and methods}

Finnish larvae were collected on 14th August 1999 in eastern Finland (PS: Heinävesi, 693:58). The identification of the genus was based on the key given by Lorenz \& Kraus (1957). The habitat was a garden with old apple and cherry trees around a house. The forest of deciduous trees with Betula, Alnus and Salix species skirted the garden to the southern and a low ridge with pine forest in the northern side of the area. The place was rather damp although the nearest lake is situated about one kilometer to the south.

All larvae were found during daytime on the underside of leaves. They were rolled up when resting. Four last instar larvae were sitting on a little Prunus cerasus-plant about 80 $\mathrm{cm}$ high from the ground and one larva on Rubus idaeus at about the same level. Later, when all leaves of Prunus had withered, all larvae fed on Rubus. Other plants were not offered for food. One last instar larva was prepared by blowing and one preserved in 70-80\% ethanol. Three larvae moulted to prepupae. One prepupa was blown and two were put in a small glass jar with fine sand and peat moss (Sphagnum sp.). Both prepupae died later in the moss and were put 


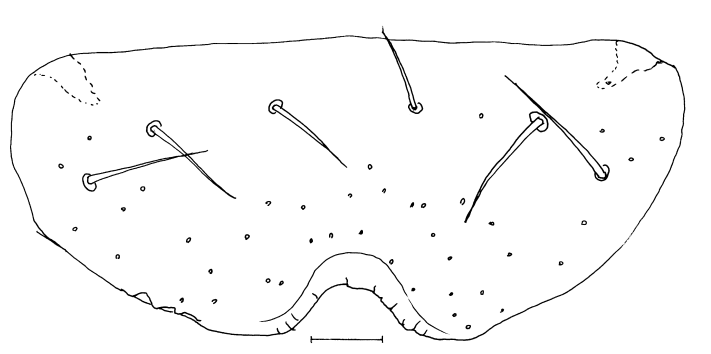

Fig. 1. Labrum from anterior view. Scale $0.1 \mathrm{~mm}$.

in ethanol. Terminology follows Viitasaari (in press), the numbering of dorsal annulets is according to Yuasa (1923) as interpreted by Vikberg \& Nuorteva (1997).

\section{Redescription of larva}

Overall description: The length of the larva varies between 25-30 mm. Head blackish-brown with bluish rim, around coronal suture more brownish, lateral sutures broadly yellowish-brown. Vertex and temples densely covered with numerous minute setae. Black spot around ocellus includes five-segmented antenna, dark brown longitudinal stripe present between this black spot and neck, parietal region narrowly yellowish-grey. Frons dark brown with greyish borders and with ca. 30 setae, yellowish grey spot on adfrontal area. Clypeus pale grey with small dark brown spot and 2 setae on each half. Labrum is symmetrical bearing 3 rather long setae on each lobe (Fig. 1). Epipharynx with row of 11 setae and one weak additional seta on right side and row of 7 setae and two weak lateral setae on left side (Fig. 2). Mandibles with 2 setae, asymmetrical, there are 5 teeth on cutting margin and two ridges with low inner tooth on first ridge on inner surface on left side but only four apical teeth and strongly developed inner tooth on right side (Figs.3-4). Maxilla: cardo with 1 seta, stipes 2, palpifer with 6 setae, 1st segment of maxillary palpus without setae, 2nd with 1 long seta, 3rd with three minute setae on apex and 4th without setae (Fig. 5). Submentum with 4 short basal and 1 lateral seta on each side, praementum with 3 basal setae, of

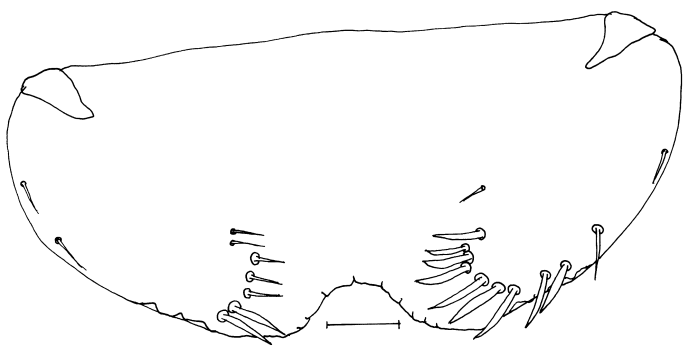

Fig. 2. Setae of epipharynx from posterior view. Scale $0.1 \mathrm{~mm}$.

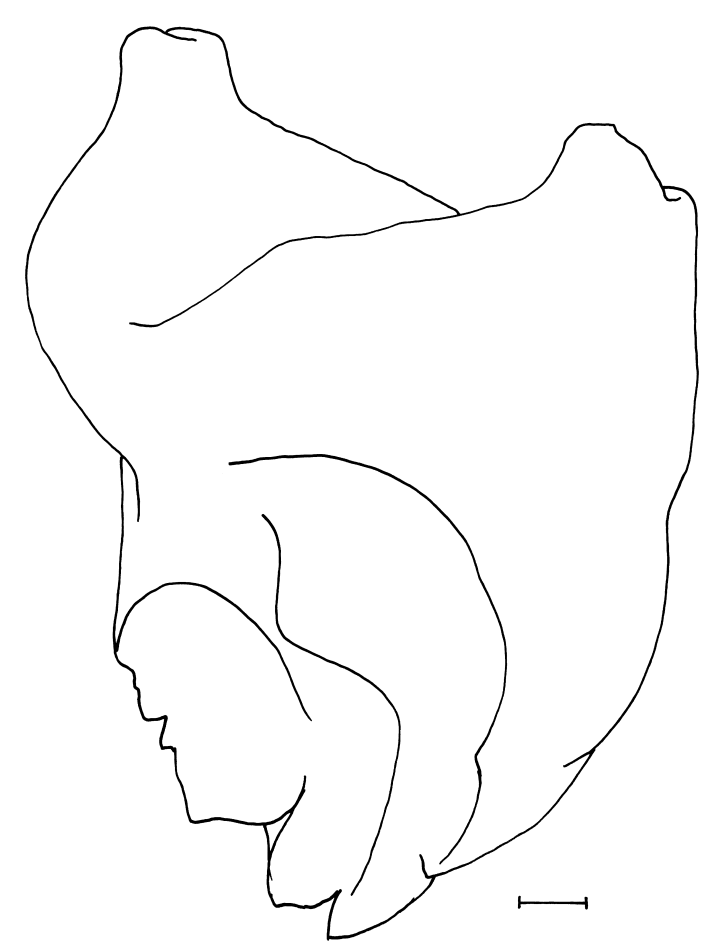

Fig. 3. Inner surface of left mandible. Scale $0.1 \mathrm{~mm}$.

which 1 very short microseta and 3 apical setae. Galea is stout, granulose apically but without setae or spines, lacinia with a row of 17 sensilla trichodea (Fig. 5). There are weak microtrichia on distal region of hypopharynx above bilobed totaglossa and stouter, conical microtrichia on two lateral lobes of posterior region, shallow medial transverse cleft present between regions (Fig. 6). 


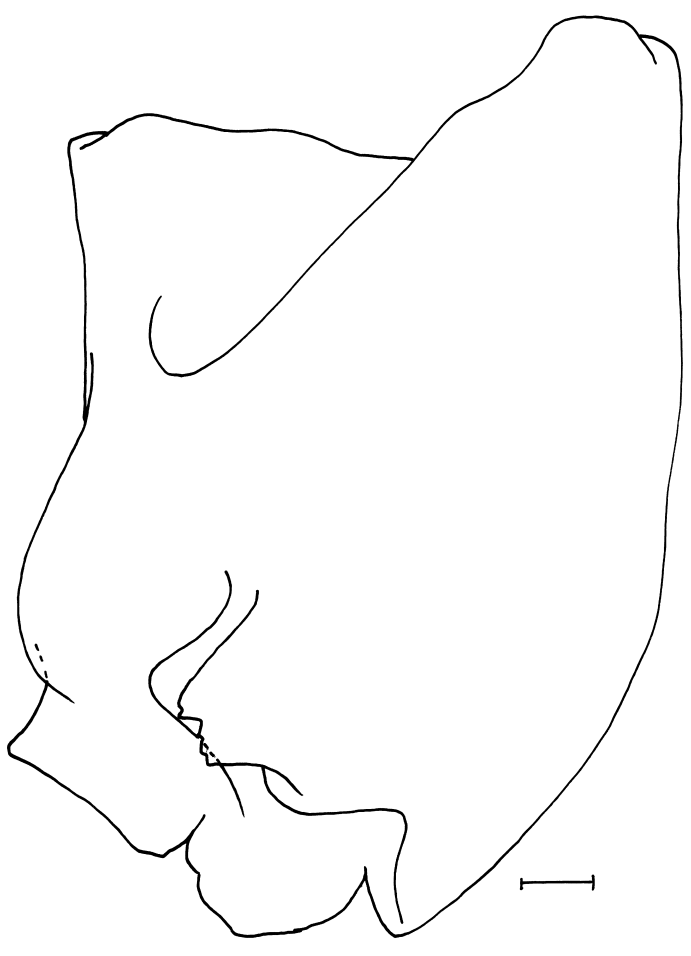

Fig. 4. Inner surface of right mandible. Scale $0.1 \mathrm{~mm}$.

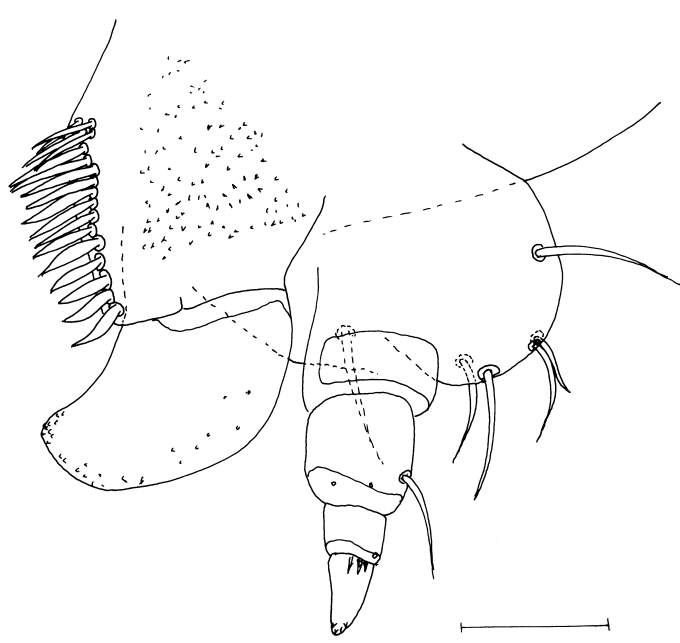

Fig. 5. Left maxillary palpus, stipes, galea and lacinia from anterior view. Scale $0.1 \mathrm{~mm}$.

2 setae present on 2nd segment of labial palpus.

Trunk: Long and large spines are present on 3rd (called here as D1) and 5th (D2) annulets, arising from enlarged orange spot. They are white

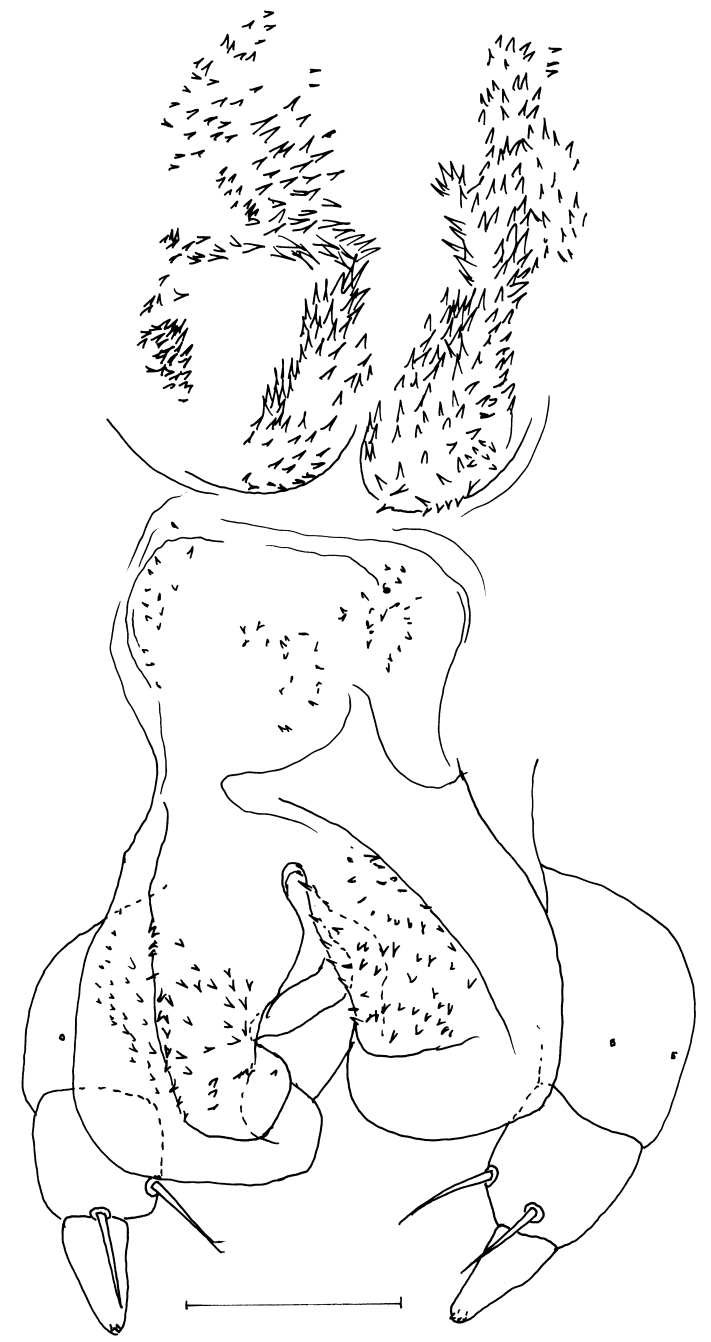

Fig. 6. Hypopharyngeal complex dorsally. Scale 0.1 $\mathrm{mm}$.

with orange basal part, apex of D2 is black. D1spines are shorter than D2 and present only on 1st-10th abdominal segments, D2 spines occur from 1st thoracic segment to 9th abdominal segment. Middorsal line white, continuous, narrow, but slightly enlarged segmentally cephalad from D1 spines, it is bordered by orange spots on 1st3rd annulets and by black transverse spots on 4th7th annulets. 2-4 black or blackish-brown spots are present on each annulet of dorsal and subdorsal zones of body, those of 3rd and 4th annulets are enlarged ventrad from D1-spines and dorsocaudad from spiracle (Fig. 7). Ground colour of 


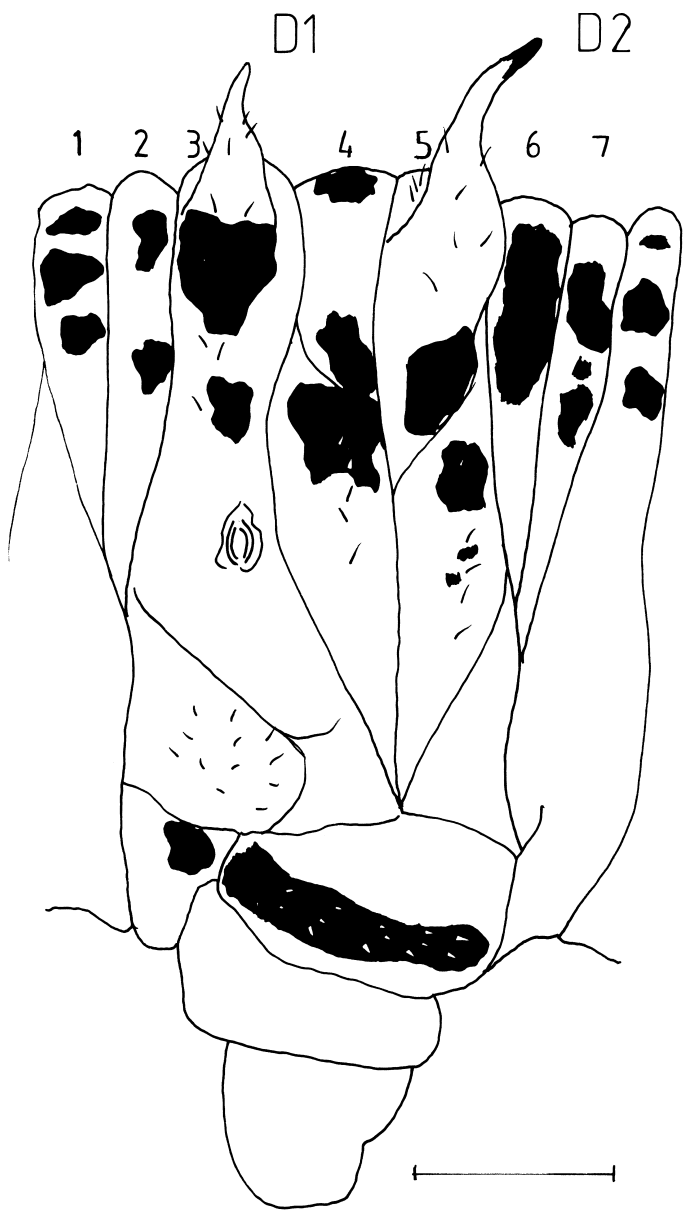

Fig. 7. 3rd abdominal segment from lateral view. Black spots refer to dark colour spots of larva. Scale $1 \mathrm{~mm}$.

dorsal and subdorsal zones of larva is white or whitish-grey. Spiracles are dark-brownish, spiracular area grey, pre- and postspiracular area white forming a white spiracular line, surpedal lobe with dark brown longitudinal stripe. Ventral zone of larva and abdominal prolegs whitish grey. Prehypopleurite of thoracic legs with dark brown spot, other part of legs pale yellowish-brown.

Thorax: Microsculpture of skin densely spinulate. Lobes rather shallow, subspiracular lobes more prominent, D2-spines long. Legs five-segmented, mesotibia with ca. 15 setae.

Abdomen: With prolegs on 2nd-8th and 10th segments. Skin spinulate. Third abdominal segment with 7 dorsal annulets, large dorsal spines on 3rd and 5th annulets, spiracles on 3rd annulet.

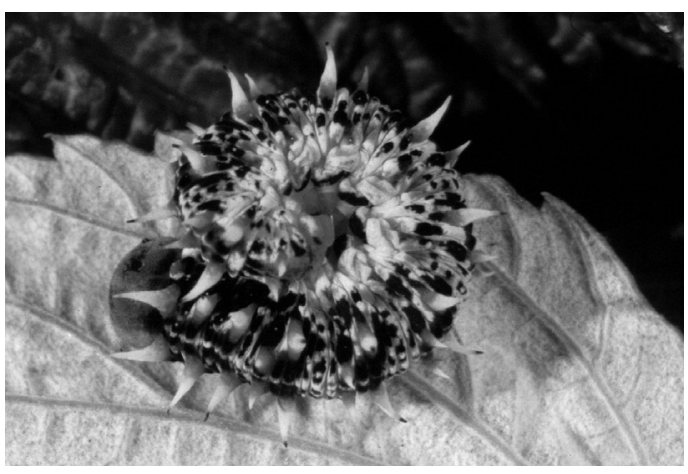

Fig. 8. Larva of Siobla ruficornis resting on the underside of a leaf of Rubus idaeus.

3rd annulet with 8 weak setae on base of D1-spine and 7 on D1-spine, 4th annulet with 5 setae on postspiracular lobe, 5 th annulet with 4 weak setae above D2-spine, 6 on D2-spine and 6 on postspiracular lobe. Other annulets without setae. There are two groups of setae on pleural zone, subspiracular lobe bears ca. 12 weak setae and surpedal lobe ca. 14 rather weak setae. Abdominal prolegs with 5 setae on inner surface, outer surface bare. 9th abdominal segment with 5 dorsal annulets. Anal shield apically rounded, covered with short weak setae, suranal and subanal lobes with numerous stouter setae.

Praepupal stage blackish grey without large dorsal spines.

\section{Discussion}

The large dorsal spines are charasteristic of the larvae of Siobla. The host plant of the species seems to vary. According to Lorenz \& Kraus (1957), the larvae of the central European species S. sturmii feed on leaves of Impatiens nolitangere L. (Balsaminaceae). Malaise (1932) found larvae of S. sibirica (=ruficornis) on Epilobium angustifolium L. (Onagraceae). Finnish larvae of S.ruficornis were found on Prunus cerasus L. and Rubus idaeus L., both of which belong to the family Rosaceae (Fig. 8). Most species of sawflies are monophagous or oligophagous, and it is rare that plants belong to different families (Kontuniemi 1951, Viitasaari 1982). Therefore, it may be possible that larvae living on Epilobium are not conspecific with those on Rosaceae, although 
some species of Tenthredininae are apparently polyphagous. Also, it is well known that different populations of herbivorous insect species can be specialized on different host plant species. However, according to Malaise's description there are no differences in habitus, except the form of the black spots on dorsal zone. However, variation like this is typical between specimens. Morphological differences remain unknown between Asian and European populations. Since the rearing was unsuccessful, comparison of adult stages was impossible. Based on adult characteristics, the genus Siobla is recently placed in a different subfamily than other genera of Tenthredinidae found in North-Europe (Lacourt 1997). Some larval characteristics support this view, e.g. palpifer with 6 setae, totaglossa bilobed with microtrichia above it and on distal region of hypopharynx, abdominal prolegs with 5 setae on inner surface at the base of apex but outer side bare, strong dorsal spines D1 and D2 present on 3rd and 5th annulets (probably synapomorphic character for Sioblinae) and 3rd and 5th annulets of 3rd abdominal segment with weak setae.

Acknowledgements. I am very grateful to Veli Vikberg, Turenki, for providing me with important references and for many valuable comments on the manuscript, Jaakko Kangas, Pälkäne, for inspiring me to make this description and Matti Viitasaari, Helsinki, for constructive discussions.

\section{References}

Forsius, R. 1919: Verzeichnis der bisher aus dem LojoGebiet bekannt gewordenen Tenthredinoiden nebst einer Übersicht sämmtlicher in Finnland festgestellter Arten. - Acta Societatis Pro Fauna et Flora Fennica 46(4): 1-25.

Gimmerthal, B. A. 1834: Einige in Livland aufgefundene und benannte Sägewespen (Tenthredininae). — Bull. Soc. Imp. Nat. Moscow 7: 122-128.

Hellén, W. 1935: Mitteilungen über einige Tenthredinoiden Finnlands. - Notulae Entomol. 15: 15-26.

Kontuniemi, T. 1951: Zur Kenntnis des Lebenszyklus der Sägewespen (Hymenoptera, Symphyta) in Finnland. Acta Ent. Fenn. 9:1-92.

Kontuniemi, T. 1960: Suomen sahapistiäistoukkien ravintokasvit. - Suomen eläimet 9: 1-104.

Lacourt, J. 1997: Contribution à une révisión mondiale de la sous-famille des Tenthredininae (Hymenoptera, Tenthredinidae). - Ann. Soc. Ent. France 32(4): 362402.

Lorenz, H. \& Kraus, M. 1957: Die Larvalsystematik der Blattwespen. - Abhandlungen zur Larvalsystematik der Insekten 1: 1-339.

Malaise, R. 1932: Entomologische Ergebnisse der schwedischen Kamtchatka-Expedition 1920-1922. Arkiv för Zoologi 23: 1-68.

Taeger, A. 1991: Zwei neue paläarktische Blattwespengattungen aus der Unterfamilie Tenthredininae (Insecta, Hymenoptera, Symphyta, Tenthredinidae). — Ent. Abh. staatl. Mus. Tierkunde Dresden 54(31): 71-95.

Viitasaari, M. 1982: Sahapistiäiset 1. Yleinen osa. Helsingin Yliopisto. Maatalous- ja metsäeläintieteen laitoksen julkaisuja $3.85 \mathrm{pp}$

Viitasaari, M. (in press): Sawflies 1. — Tremex Press, Helsinki

Viitasaari, M. \& Vikberg, V. 1985: A checklist of the sawflies (Hymenoptera, Symphyta) of Finland. - Not. Entomol. 65: 1-17.

Vikberg, V. \& Nuorteva, M. 1997: On the rearing of Nesoselandria morio (Fabricius) and Birka cinereipes (Klug) (Hymenoptera, Tenthredinidae), with descriptions of their larvae. - Entomol. Fennica 8: 27-38.

Yuasa, H. 1923(1922): A classification of the larvae of the Tenthredinoidea. — Illinois Biol. Monogr. 7(4): 1-172. 